The Federal Reserve BanK of Kansas City Research Working Papers

Driver of Choice? The Cost of Financial Products for Unbanked Consumers

Fumiko Hayashi, Josh Hanson, and Jesse Leigh Maniff

November 2015

RWP 15-15 


\title{
Driver of Choice? The Cost of Financial Products for Unbanked Consumers
}

\author{
Fumiko Hayashi, Josh Hanson, and Jesse Leigh Maniff \\ Federal Reserve Bank of Kansas City ${ }^{\dagger}$
}

November 2015

\begin{abstract}
This paper examines whether some of the unbanked consumers' choice of general purpose reloadable (GPR) prepaid cards over checking accounts and alternative financial service (AFS) products can be explained by the cost incurred by those consumers. We compare the three types of products by constructing consumer models based on the actual behavior of GPR prepaid cardholders and applying those models to the fee schedules of actual products offered in the market. Overdrafts are a major factor affecting the cost rankings. For consumers who regularly or occasionally overdraw their accounts, checking accounts are more costly than GPR cards or AFS products. In contrast, for consumers who do not need overdraft capability and short-term credit, GPR cards are more costly than checking accounts. The cost difference across the products clearly explains the former type of consumers' choice of financial products, while it does not explain the latter type of consumers' choice.
\end{abstract}

JEL Classification: D12; E42; G21

Keywords: General Purpose reloadable prepaid cards, Checking accounts, Alternative financial services, Overdraft, Unbanked

\footnotetext{
${ }^{\dagger}$ Payments System Research, Federal Reserve Bank of Kansas City. E-mail: fumiko.hayashi@kc.frb.org. The authors thank participants at the Federal Reserve Bank of Kansas City seminar for their valuable comments. The authors wish to acknowledge and thank NetSpend for generously providing the data used in this paper. The views expressed herein are those of the authors and do not necessarily reflect the views of the Federal Reserve Bank of Kansas City or the Federal Reserve System.
} 


\section{Introduction}

Nearly 28 percent of U.S. households are either unbanked or underbanked, meaning they either do not have a checking or savings account, or have a bank account but also use alternative financial services (AFS) outside the banking system (Federal Deposit Insurance Corporation (FDIC) 2013). These underserved consumers are increasingly turning to general purpose reloadable (GPR) prepaid cards to access electronic payment methods and address their financial transaction needs.

GPR prepaid cards provide a wide range of functionality. They are branded by at least one major payment card network, like American Express, Discover, MasterCard, Visa, or a PIN debit network and allow cardholders to make purchases and cash withdrawals anywhere those card brands are accepted, including merchants, ATMs, and online. GPR prepaid cards also allow cardholders to make bill payments and receive direct deposits, such as payrolls and government benefits, using the automated clearinghouse (ACH). Cardholders can also load value onto their cards using cash at retail locations that participate in a reload network. A few GPR prepaid card providers even offer overdraft capability.

Why underserved consumers rely on prepaid cards and other AFS products instead of checking accounts is still unclear; however, perceived costs appear to have a significant effect on their behavior. ${ }^{1}$ In fact, the most commonly cited reasons for being unbanked include high or unpredictable bank account fees and lack of enough money to meet a minimum balance requirement (FDIC 2013). Fees associated with overdrafts are viewed as some of the most unpredictable bank account fees and many GPR prepaid cardholders avoid these fees by having a GPR prepaid card that does not offer overdraft capability. To access short-term credit, those

\footnotetext{
${ }^{1}$ A qualitative study on why underserved consumers use alternative financial services and how they develop strategies to satisfy their basic transaction needs was conducted by the Federal Reserve Bank of Kansas City (2010).
} 
cardholders may use other AFS credit products, such as payday and car-title loans. ${ }^{2}$ Some GPR prepaid cardholders, on the other hand, hold a GPR prepaid card that offers overdraft capability and make a deliberate decision to overdraw their account and pay overdraft fees (Hayashi and Cuddy 2014b). Even if GPR prepaid cards were more costly than checking accounts, they might be less costly than solely depending on other alternatives, such as check cashing, money orders and remittances for bill payments, and payday and car-title loans.

Understanding the costs of various financial products for underserved consumers is important not only for those consumers but also for payment service providers and policymakers. It will help financial institutions and providers of AFS to design products that meet the underserved consumers' needs. By keeping comprehensive financial product options and their costs for underserved consumers in perspective, policymakers can make more informed policy decisions and avoid the unintended negative consequences these policies may have on the most vulnerable consumers.

A few previous studies have examined the costs of checking accounts and GPR prepaid cards but the results significantly vary by consumer behavior, such as overdrafts and direct deposits. The Pew Charitable Trusts (2012), for example, found that "savvy" consumers who receive direct deposits and avoid overdraft and other fees whenever possible incur higher total fees on GPR prepaid cards than on checking accounts. However, consumers who make two overdraft transactions per month generally incur lower total fees on GPR prepaid cards than on checking accounts. Bretton Woods (2013) concluded GPR prepaid cards are generally less expensive than checking accounts for consumers who make overdraft transactions, regardless of direct deposit status. Despite the importance of consumer models when comparing costs

\footnotetext{
${ }^{2}$ Some low- and moderate-income households use AFS loans to pay for living expenses, such as paying off bills and covering recurring expenses (Barr 2012).
} 
between checking accounts and GPR prepaid cards, these studies did not necessarily use consumer models that represent the behavior of GPR prepaid cardholders.

This paper examines whether some of the unbanked consumers' choice of GPR prepaid cards over checking accounts and AFS products can be explained by the cost incurred by those consumers. We compare costs of GPR prepaid cards, checking accounts, and AFS products for unbanked consumers, or those consumers who use GPR prepaid cards as a substitute for a checking account. We construct two consumer models that represent GPR prepaid cardholders who receive direct deposits each month. One consumer model assumes consumers do not need overdraft capability—more precisely, consumers do not opt in to overdraft programs and do not use other short-term credit products either. The other model assumes consumers need overdraft capability or short-term credit. Our consumer models are based on the actual payment behavior observed in the data furnished by NetSpend, a leading prepaid card provider and one of the few that offer overdraft programs. These consumer models are applied to the fee schedules of actual products offered in the market. We manually collect fees and other information necessary to calculate costs of checking accounts, GPR prepaid cards, and AFS products from publicly available documents.

Similar to the previous studies, our results suggest cost rankings—or the ordering of product types from the least to the most expensive - depend on consumer behavior, especially overdraft behavior. For consumers who need neither overdraft capability nor short-term credit, checking accounts are generally less expensive than GPR prepaid cards and other AFS products. In contrast, for consumers who use overdraft or short-term credit, checking accounts are much more expensive than GPR prepaid cards and AFS products. This is partly due to significantly higher fees charged for an overdraft transaction by banking institutions. For both types of 
consumers, whether GPR prepaid cards are less costly than other AFS products depends on providers. The cost difference across the three types of products clearly explains the unbanked consumers' propensity to use GPR prepaid cards over checking accounts, but only for unbanked consumers with regularly occurring overdrafts or short-term credit needs. The cost difference does not explain the choice by unbanked consumers who do not need overdraft capability and short-term credit. For them, having a checking account and using it more exclusively is less costly than using a GPR card or AFS products.

This paper is organized as follows. Section 2 discusses options for underserved consumers to access electronic payments methods and short-term credit. It also reviews previous literature comparing the cost of checking accounts and GPR prepaid cards. Section 3 constructs two consumer models from data furnished by NetSpend and describes fee data from actual checking accounts, GPR prepaid cards, and AFS products. Section 4 provides the results and Section 5 offers a conclusion.

\section{Background}

\subsection{Underserved consumers access to electronic payments and short-term credit}

A sizable percentage of U.S. households are financially underserved. According to the most recent survey conducted by the FDIC, 7.7 percent of U.S. households did not have a checking or savings account in 2013 and thus are considered unbanked. An additional 20 percent of U.S. households are considered underbanked, meaning they had a bank account but also used AFS products outside the banking system. Approximately 16.7 million U.S. adults were unbanked and 50.9 million U.S. adults were underbanked in 2013.

Underserved consumers have been traditionally dependent on AFS products for their transaction and short-term credit needs. For transaction needs, they have used nonbanks' money 
orders and remittances for remote payments where in-person cash payments are unavailable, and check cashing to receive payrolls, government benefits, or other funds. AFS credit products include payday loans, car-title loans, refund anticipation loans, pawn shops, and rent-to-own services. Transaction AFS products are more widely used than credit AFS products. In 2013, 60.5 percent of unbanked households had used one or more transaction AFS products in the previous 12 months and 16.7 percent used one or more AFS credit products in that time. ${ }^{3}$

Underserved consumers, however, are increasingly turning to GPR prepaid cards. Among unbanked households, the share of households that had ever used a GPR prepaid card substantially increased to 27.1 percent in 2013 from 17.8 percent in 2011, while among underbanked households, the share slightly increased to 19.7 percent from 17.4 percent. The share of households that used GPR prepaid cards in the prior twelve months and the share of households with GPR prepaid cards that have reloaded their cards in the prior twelve months varied significantly by banking status. More than 22 percent of unbanked households used GPR prepaid cards in the last 12 months, which is substantially higher than 13.1 percent of underbanked households or 5.3 percent of fully banked households. Nearly 58 percent of the unbanked households that used GPR prepaid cards have reloaded their cards at least once in the last 12 months, while 42.9 percent of the underbanked and 23.4 percent of the fully banked households that used GPR prepaid cards have done so.

GPR prepaid cards provide a wide range of functionality. First, they can be used just like debit cards. Cardholders can make purchases at any brick-and-mortar or online merchant who accepts the card brand(s) on their card, such as Visa, MasterCard, American Express, Discover, or a PIN debit network. Cardholders also can obtain cash at ATMs, or at retailers using a cashback function of PIN debit. Second, GPR prepaid cards can send and receive ACH payments,

\footnotetext{
${ }^{3}$ By definition, all underbanked households had used one or more transaction or credit AFS products.
} 
just like checking accounts. In addition to a 16-digit card number (similar to credit and debit cards), GPR prepaid cards typically have a separate 10-14 digit account number (including bank routing number and individual account number), which is used to receive direct deposits or pay bills via ACH. Third, some GPR prepaid card providers offer person-to-person transfer services among their cardholders. Fourth, a few GPR prepaid card providers offer overdraft capability.

Given these functions, GPR prepaid cards can substitute not only for checking account products (debit cards and ACH) but also for AFS transaction and credit products. Instead of gathering cash and coins to conduct a purchase at any store, cardholders can simply use their card and have the bill deducted from their card account. Instead of traveling to a retail location or a money transmitter to purchase a money order for bill payment, cardholders can simply provide the card number to billers or go online and submit their payments through their prepaid card provider's website at little or no cost. Instead of using check cashing, cardholders can receive their paychecks or government benefits electronically as direct deposits. Funds can also be electronically transferred between accounts, eliminating the need to transfer funds by means of a money order or money remittance. Furthermore, overdraft availability from GPR prepaid card providers may reduce the demand of underserved consumers for short-term credit products, such as payday loans and car-title loans.

\subsection{Previous Literature}

As GPR prepaid cards have gained more popularity, literature on costs and fees on those cards has emerged. Wilshusen et al. (2012) and Hayashi and Cuddy (2014a) examined actual fees incurred by GPR prepaid cardholders. Both studies found the actual amount of fees had a wide range. A cardholder at the first quintile incurred less than $\$ 2$ in a month, while a cardholder 
at the fifth quintile incurred over $\$ 10$ in Wilshusen et al. and over $\$ 25$ in Hayashi and Cuddy. The fee variation was mainly explained by the variation of transaction patterns.

Our paper is more closely related to another group of studies that compared costs and features among GPR prepaid cards or between those cards and checking accounts. Most of these studies used a common methodology. They first constructed consumer models and then applied the models to actual checking accounts and GPR prepaid cards offered in the market. Factors included in the consumer models vary by study, but they typically include the numbers of purchases, of cash withdrawals, and of bill payments, whether to receive direct deposits, and whether to make overdraft transactions. The selection method of checking accounts and GPR prepaid cards in the sample also varies by study.

The most detailed consumer models are used in Pew Charitable Trusts (2012). It constructed three consumer models based on the consumer's financial literacy. The level of financial literacy differentiates consumer behavior regarding direct deposit use, overdrafts, and use of fee-based services, such as balance inquiry and customer service. However, the monthly amount of load or deposit on an account and the monthly numbers of purchases, cash withdrawals and bill payments are assumed to be the same across the three types of consumers. In contrast, Bretton Woods (2013) used relatively simpler consumer models. Based on the consumer model constructed in a study by a staff attorney of Consumers Union (Jun 2010), Bretton Woods assumed two types of consumers: one who receives direct deposits and the other who does not. Both types of consumers are, however, assumed to have the same transaction pattern, with respect to purchases, cash withdrawals, bill payments, balance inquiries, and overdrafts. These two studies selected consumers' transaction patterns somewhat arbitrarily. For example, Bretton Woods assumed eight purchases per month. These purchases include four 
monthly purchases at the grocery store and four monthly meals purchased at restaurants. Pew's study, on the other hand, assumed 17 purchases per month, which coincides with the average number of monthly purchases among active debit card users.

The two studies used different approaches to apply their consumer models to actual checking accounts and GPR prepaid cards. For checking accounts, both studies selected 12 or 13 of the largest banks. While Bretton Woods chose the entry level, basic checking product from each of the 13 banks, Pew included 237 checking accounts offered by the 12 banks in the sample. For GPR prepaid cards, Bretton Woods selected 11 products, each from different providers. In contrast, Pew included 52 products in the sample, some of which are offered by the same providers. Bretton Woods takes the approach of comparing the banks' lowest cost checking account products and GPR prepaid card provider's lowest cost products, while Pew's approach is comparing all available checking and GPR prepaid products.

The two studies demonstrated costs of checking accounts and GPR prepaid cards are significantly influenced by consumer behavior, such as direct deposit use and overdrafts. Cost ranking — whether GRP prepaid cards are less costly than checking accounts—also varies by consumer behavior. Pew's study showed that GPR prepaid cards are generally more costly than checking accounts for "savvy" consumers who receive direct deposits and do not make overdrafts, while GPR prepaid cards are generally less costly than checking accounts for consumers who do not receive direct deposits and do make overdrafts. Assuming overdrafts for both types of consumers, Bretton Woods showed consumers who receive direct deposits incur lower fees for both checking accounts and GPR prepaid cards than consumers who do not receive direct deposits. It also showed GPR prepaid cards are generally less expensive than checking accounts regardless of direct deposit status. 


\section{Methodology and Data}

Our study compares the costs of checking accounts, GPR prepaid cards, and AFS

products. We focus on unbanked consumers, or those consumers who use GPR prepaid cards as a substitute for a checking account. ${ }^{4}$ Using NetSpend data, we construct two consumer models that represent GPR prepaid cardholders who receive direct deposits each month. One type of consumer does not need overdraft capability ("non-overdrafters"), while the other type needs overdraft capability or short-term credit (“overdrafters”). Our comparison includes checking accounts offered by three groups of banks — national, large regional, and smaller community banks. We also include AFS products, such as check cashing, money orders and remittances for bill payments, and short-term credit products like payday and car-title loans, as a supplement or a substitute for GPR prepaid cards. ${ }^{5}$

\subsection{NetSpend data and consumer models}

In order to reflect actual GPR prepaid cardholders' usage pattern with our consumer models, we use data furnished by NetSpend. NetSpend is a leading prepaid card provider and one of the few that offer overdraft programs. No other leading prepaid card provider (e.g., Green Dot, American Express, Chase, and other large banks) offers an overdraft program.

The NetSpend data contain all active GPR prepaid card accounts over a one-year period between July 1, 2011 and June 30, 2012. An active account is defined as an account whose holders made at least one debit transaction during the one-year timeframe. The data consist of

\footnotetext{
${ }^{4}$ Many GPR prepaid cardholders also have a checking account and thus use GPR cards as a complement to a checking account (Herbst-Murphy and Weed 2014).

${ }^{5}$ To get a payday loan, consumers are typically required to have a bank account in relatively good standing. According to the survey data of FDIC (2014), however, 18 percent of unbanked households who did not have a bank account in the past 12 months have used a payday loan within the past 12 months, suggesting payday loans are accessible for at least some consumers without a bank account.
} 
more than three million accounts and include various types of information such as reloads, overdrafts, transactions, and incurred fees. ${ }^{6}$

For our consumer models, we use accounts that received direct deposits periodically, which are approximately 23 percent of all accounts in the data. ${ }^{7}$ These accounts are divided into two groups to represent two types of consumers-overdrafters and non-overdrafters. To represent overdrafters, we use a group of NetSpend cardholders, who opted in to the overdraft program and overdrew their accounts by more than $\$ 10$ at least once. To represent nonoverdrafters, we use the other group of NetSpend cardholders, who never overdrew their accounts by more than $\$ 10 .{ }^{8}$ Even if NetSpend cardholders did not opt in to the overdraft program, they may have overdrawn their accounts by $\$ 10$ or less because NetSpend provides a free-of-charge, non-enrollment based overdraft buffer for up to $\$ 10$ on a negative balance. ${ }^{9}$ About 20 percent of account holders who receive direct deposits periodically are in the former group and the rest are in the latter group.

Table 1 describes the average monthly activities of these two groups. On average, the first group representing overdrafters receives direct deposits 2.1 times per month, while the second group representing non-overdrafters receives them 1.8 times per month. In addition to direct deposits, both groups make cash loads less than once per month. The average monthly load amount is $\$ 1,439$ for overdrafters and $\$ 1,091$ for non-overdrafters. Overdrafters tend to make more ATM and purchase transactions than non-overdrafters. The average numbers of

\footnotetext{
${ }^{6}$ See Hayashi and Cuddy (2014a) for more details about the NetSpend data.

7 An account is defined as "periodic direct deposits" if the ratio of the number of direct deposits in the entire account lifespan to the account lifespan in months is 0.9 or greater.

${ }^{8}$ Ideally, non-overdrafters would be represented by cardholders who did not opt in to the overdraft program, but whether a cardholder has opted in to the overdraft program is unobservable in the data unless the cardholder overdrew his/her account by more than $\$ 10$. As a result, the usage pattern of non-overdrafters in our model is derived from a group of NetSpend cardholders who did not opt in to the overdraft program as well as those who opted in to the overdraft program but have never overdrawn their account by more than $\$ 10$.

${ }^{9}$ See Hayashi and Cuddy (2014b) for more details about NetSpend's overdraft program and overdraft buffer.
} 
ATM and purchase transactions made in a month by overdrafters are 3.4 and 20.2, while those by non-overdrafters are 2.5 and 13.9. About 10 percent of "purchase" transactions are paid to billers, and thus these are in fact bill payments processed over card networks. The average amount per transaction paid to billers is around $\$ 95$. NetSpend cardholders can also make bill payments using $\mathrm{ACH}$ via online portal (similar to online banking), but such bill payments are rarely made.

The second half of Table 1 shows activities other than loads and debit transactions. By definition, non-overdrafters do not make any overdraft transaction that overdraws their account by more than the $\$ 10$ value of an overdraft buffer, although they, as well as overdrafters, have less than one transaction in a month to which overdraft buffer applies. Overdrafters make 2.5 overdraft transactions in a month on average, but they typically incur only 0.8 overdraft fees for those 2.5 overdraft transactions. Many overdrafters avoid incurring overdraft fees by taking advantage of a 24-hour window offered by NetSpend to bring their balance back to zero or positive (Hayashi and Cuddy 2014b). Both groups of account holders have declined ATM, purchase, and $\mathrm{ACH}$ transactions. While declined purchase and $\mathrm{ACH}$ transactions rarely occur, declined ATM transactions occur once every two months for overdrafters and once every four months for non-overdrafters, on average. Both groups inquire about their accounts' balance once every two months via ATM and three times in two months using customer service calls. The average daily balance is a little over $\$ 100$ : $\$ 119$ for overdrafters and $\$ 125$ for non-overdrafters. Overdrafters and non-overdrafters keep their account balance negative for 12.3 days and 8.5 days, respectively, in a month on average. Although non-overdrafters do not make any overdraft transactions, their balance can be negative partly due to overdraft buffer offered by NetSpend. 
We now turn to our consumer models. In the models, we assume consumers do not change their payment and/or overdraft behaviors based on the types of products they use. In other words, we assume even when consumers happen to have a checking account or depend solely on AFS products, they continue to have the same payment and/or overdraft behaviors as they would be using a GPR prepaid card.

The first model describes overdrafters, who opt in to an overdraft program when available, or otherwise use short-term credit products (Table 2A). This group of consumers makes 2.6 deposits to a checking account or the same number of loads on a GPR prepaid card with the total amount of $\$ 1,439$ per month. Among them, 2.1 deposits/loads are direct deposits with the aggregate value of $\$ 1,335$ and the rest are other types of deposits (to a checking account) or cash loads (on a GPR card). If these consumers have neither a checking account nor a GPR card, they use check-cashing services 2.6 times per month.

The number of purchases and its distribution across PIN and signature card-present (CP), and signature card-not-present $(\mathrm{CNP})$ are the same regardless of whether the consumers have a checking account or a GPR card. In a month, they make 20.2 purchases, of which 7.5 are conducted with PIN, 4.8 with signature CP, and 7.9 with signature CNP. Among these transactions, 2.0 transactions with the total amount of $\$ 190$ (\$95 each) are paid to billers. If the consumer completely depends on AFS, he makes two $\$ 95$ bill payments using money orders or remittance services.

The number of ATM cash withdrawals per month varies by product type because banks and GPR prepaid card providers treat ATM cash withdrawals that cause overdraft differently: it is 4.0 if the consumers have a checking account and 3.4 if they have a GPR card. ATM cash withdrawals are inapplicable if the consumers completely depend on AFS. The variation comes 
from declined ATM cash withdrawals. NetSpend cardholders who overdraw their accounts have about 0.6 declined ATM cash withdrawals per month, thus we assume these transactions continue to be declined if overdrafters have a GPR card. If they have a checking account, these transactions are assumed to be approved by their banks as overdraft transactions. The number of ATM cash withdrawals is divided into the numbers of in-network withdrawals and of out-ofnetwork withdrawals, because the costs of using in-network ATMs are much lower than those of using out-of-network ATMs. Based on the actual distribution between in-network and out-ofnetwork ATM cash withdrawals among checking account holders, we assume 85 percent of ATM transactions made by checking account holders are at in-network ATMs. ${ }^{10}$ In contrast, 7 percent of ATM transactions made by holders of GPR cards offered by nonbanks are made at innetwork ATMs or surcharge-free ATMs. ${ }^{11}$ Although there is no information about in- vs. out-ofnetwork ATM distribution for holders of GPR cards offered by banks, we assume 85 percent of their ATM transactions are made at in-network ATMs.

The number and value of overdraft transactions per month also vary by product type. If the consumers have a checking account, we assume they make 3 overdraft transactions with a total value of $\$ 156$. Three overdraft transactions are the approximation of the sum of overdraft transactions (2.5), and ATM transactions that result in overdrafts (0.6). ${ }^{12}$ The total overdraft value takes into account the average value of purchase/ATM transactions (\$51.8). In contrast, if the consumers have a GPR card with overdraft capability, they make 2.5 overdraft transactions, 0.8 of which incur overdraft fees. If the consumers have a GPR card without overdraft capability

\footnotetext{
${ }^{10}$ The distribution among checking account holders is obtained from a report by Government Accountability Office (GAO) (GAO 2013). About 86 percent of ATM withdrawals made by checking account holders at large banks or 84 percent at mid-size banks were at in-network ATMs, thus not incurring a surcharge.

${ }^{11}$ According to Hayashi and Cuddy (2014a), about 93 percent of ATM withdrawals made by NetSpend cardholders in June 2012 were assessed a surcharge, suggesting only 7 percent of ATM withdrawals were made at in-network or surcharge-free ATMs among holders of GPR cards offered by nonbanks.

${ }^{12}$ Some banks charge no overdraft fees for a $\$ 5$ or less overdraft transaction.
} 
or completely depend on AFS, we assume they make a payday or car-title loan of \$130 in a month. $^{13}$

To complete the first consumer model, we assume the consumers make 1.7 balance inquiries ( 0.4 via ATM and 1.3 via customer service calls), have the average daily balance of $\$ 119$, and have 12 days with negative balance in a month regardless of whether they have a checking account or a GPR card. Among 0.4 balance inquiries via ATM, we assume the consumers incur no surcharge if they have a checking account or a bank's GPR card, while they incur surcharges for all 0.4 inquiries if they have a nonbank's GPR card. This assumption is based on the distribution between in-network and out-of network ATM usage among checking account holders and among nonbanks' GPR card users.

The second model describes non-overdrafters, who do not opt in to an overdraft program and do not use short-term credit products (Table 2B). Non-overdrafters make a slightly smaller monthly number $(2.5)$ and amount $(\$ 1,091)$ of deposits to a checking account, loads on a GPR card, or check-cashing than overdrafters. The number of purchases is 13.9 per month, 1.4 of which being paid to billers. Regardless of whether the consumers have a checking account or a GPR card, they make 2.5 ATM cash withdrawals and have 0.3 declined ATM transactions per month. These consumers make no overdraft transactions and no short-term loans. The consumers make 2.0 balance inquiries: 0.5 via ATM and 1.5 via consumer service calls. Their average daily balance is $\$ 125$.

\subsection{Fee data}

To apply the two models constructed above to actual checking accounts, GPR prepaid cards, and AFS products offered in the market, we collect fee data for those products. Checking

\footnotetext{
${ }^{13}$ The value of loan, $\$ 130$, is derived by multiplying $\$ 51.8$, the average value of purchase/ATM transaction, and 2.5 , the number of overdraft transactions.
} 
accounts are divided into three groups based on their deposit size: largest national banks, large regional banks, and smaller community banks. ${ }^{14}$ GPR prepaid cards have three types. First, they are divided into two groups based on whether they are offered by banks or nonbanks. While all GPR cards offered by banks have no overdraft capability, nonbanks' GPR cards are further divided into two groups: cards with and without the overdraft capability. We consider three AFS products: check cashing, money orders or remittances for bill payments, and payday or car-title loans for short-term loans.

Three bank samples_-largest national, large regional, and smaller community bank samples — are created to represent banking institutions of different sizes. All samples contain banks that offer checking accounts to average consumers, thus investment banks, banks that offer deposit accounts to high-net-worth consumers only, and banks specializing in credit card accounts are excluded.

The largest national bank sample contains the banks with deposits totaling \$20 billion or more in 2014, according to the FDIC's Summary of Deposits. Twenty nine banks are identified as banks that meet both account offering and deposit size criteria. Our sample includes all 29 banks.

The large regional bank sample contains banks in the Tenth District of the Federal Reserve System with deposit size falling in the range from $\$ 600$ million to $\$ 20$ billion. ${ }^{15}$ Among the total of 51 banks that meet the criteria, 43 banks are included in our sample and 8 banks are excluded due to missing fee information. ${ }^{16}$

\footnotetext{
${ }^{14}$ Online-only checking accounts are excluded.

${ }^{15}$ The Tenth District of the Federal Reserve System includes Colorado, Kansas, Nebraska, Oklahoma, Wyoming, and portions of western Missouri and northern New Mexico.

${ }^{16}$ Those 43 banks in our sample tend to have greater deposits than their population of 51 banks. Both the null hypotheses that our sample mean is equal to or smaller than the population mean are rejected.
} 
The smaller community bank sample is randomly drawn from banks in the Tenth District of the Federal Reserve System with deposit size less than $\$ 600$ million. We first draw 150 banks from the total of 874 banks and then exclude banks with missing fee information. Forty-eight banks remain in our sample. $^{17}$

We focus on the fees for the most basic checking account offered by each bank to ensure the fee statistics we create are relevant for underserved consumers. ${ }^{18} \mathrm{We}$ also focus on overdraft programs rather than overdraft protections. Overdraft programs allow checking account holders to overdraw their account and assess fixed overdraft fees. In contrast, overdraft protections allow checking account holders to link credit products to cover overdrafts and assess finance or interest charges to the users. Linkable credit products may include dedicated overdraft lines of credit, multipurpose personal lines of credit, credit cards, and home equity lines of credit (CFPB 2013). Typically, overdraft protections are less costly than overdraft programs. However, overdraft protections are offered to qualified consumers only and underserved consumers may not be qualified for these protections.

Fee information for every bank included in our samples was collected via a bank's website, email, or a live online chat with bank representatives available on their institution's website between December 2014 and July 2015. The fee information is gathered from fee schedules and overdraft policy disclosure notices. Banks are excluded from our sample if their fee schedules and overdraft policy were not available.

\footnotetext{
${ }^{17}$ About 50 banks in our sample tend to have greater deposits than their population of 874 banks. Although the null hypothesis that our sample mean is equal to the population mean is not rejected, the null hypothesis that our sample mean is smaller than the population mean is rejected.

${ }^{18}$ Banks that actively engage in community development and outreach efforts may offer affordable financial services to low-income individuals and families and may not make the information about those services' fees available to general public. If this is the case, our cost estimation in the following section may be upward-biased.
} 
In addition to overdraft fees that are assessed for each overdraft, some banks assess an extended overdrawn fee if the account holder does not make a deposit to bring the account balance back to positive within a specified period of time after incurring an overdraft. ${ }^{19}$ Although some banks explicitly state the non-existence of an extended overdrawn fee, quite a few banks provide no information about such a fee. If we exclude those banks with missing information about an extended overdrawn fee, the size of our samples, especially the regional bank and the community bank samples, is significantly reduced (from 43 to 32 for the regional bank sample, and from 48 to 27 for the community bank sample). Thus, we keep those banks in our samples and assume they do not assess an extended overdrawn fee. This treatment may cause underestimation of fee statistics because some banks without extended overdrawn fee information may assess such a fee to their account holders. Nevertheless, the results are qualitatively similar and the cost ranking does not change even if we exclude banks without extended overdrawn fee information, which likely causes overestimation of fee statistics.

The GPR prepaid card sample includes 24 providers. Ten providers are banks and the rest are nonbanks. Only one provider, NetSpend, is identified as offering an overdraft program. All providers in the sample offer a direct deposit function to their cardholders. Some providers offer different fee programs to their cardholders. The two most common fee programs are a monthly fee program and a pay-as-you-go program. A monthly fee program assesses a monthly fee but does not assess a per-transaction fee for purchase transactions. A pay-as-you-go program is the opposite: it does not assess a monthly fee but assesses a per-transaction fee for purchase transactions. When multiple fee programs are offered by a provider, we assume the cardholders described in our consumer models select the lowest possible fee program. Monthly fee programs

\footnotetext{
${ }^{19}$ According to CFPB (2013), 21 of the top 33 institutions in the research firm's database charged an extended overdrawn fee in 2012.
} 
are generally less costly than pay-as-you-go fee programs for the two types of consumers in our models due to a relatively large number of purchase transactions.

Our approach to the collection of fee information for AFS products is slightly different from the approach for checking account and GPR card products described above. Our consumer models identify three AFS products—check cashing, money orders or remittances for bill payments, and payday or car-title loans for short-term credit—-that are used to supplement or substitute for GPR prepaid cards. We collect fee information for each product and then aggregate their fees based on the consumer models. We start with the fee reported as a "typical" fee or fee range for a given product.

For check-cashing, two large national check-cashing chains charge up to 3 percent of the check amount. ${ }^{20}$ Some banks charge 1 to 3 percent of the check amount or a fixed fee of $\$ 10$. A large retailer charges $\$ 3$ for a check of $\$ 1,000$ or less and $\$ 6$ for a check of $\$ 1,001$ to $\$ 5,000$. We use these fees to estimate the range of check-cashing fees.

Money orders can be used for paying bills. The United States Postal Service (USPS) offers money orders and charges a fee of $\$ 1.25$ for each money order of $\$ 500$ or less. Some retailers charge $\$ 0.7$ for each money order up to $\$ 500$ or a higher amount. Banks also offer money orders and they may charge a fee of $\$ 5$ or more for each money order up to at least $\$ 500 .{ }^{21}$ Bill payment services are also offered by money transmitters. ${ }^{22}$ Their fees vary by their agent and by speed. The standard delivery, which typically takes 3 days for the bill payment to reach the biller, is less costly than the next day delivery, and the expedited same day delivery is the most expensive. In our study, we assume the consumers in our model use the standard delivery. The standard delivery bill payment fee ranges from $\$ 1.00$ to $\$ 1.50$.

\footnotetext{
${ }^{20}$ These fees are reported in Bell (2011).

${ }^{21}$ These fees are reported in Morales (2015).

${ }^{22}$ Unlike money orders, these payments may not be accepted by some billers.
} 
Collecting fees for payday and car-title loans is difficult partly because the terms of these loans are regulated by many states. The average cost for borrowers of payday or car-title loans is estimated around $\$ 15$ or $\$ 25$ for every $\$ 100$ (Edmiston 2010; Montezemolo 2013). We use these figures to estimate the cost of short-term credit as an alternative to overdrafts.

\section{Results}

\subsection{Total cost comparison}

Our results confirm that overdrafts are a major factor affecting cost rankings among three types of products: checking accounts, GPR prepaid cards, and other AFS products. For consumers who regularly make overdraft transactions, GPR prepaid cards are significantly less costly than checking accounts (Table 3, Pane A). The average total cost of checking accounts per month ranges between $\$ 86$ and $\$ 112$, while that of GPR prepaid cards ranges between $\$ 38$ and \$57. Since all GPR prepaid card providers except NetSpend do not offer overdraft capability, their cards' total costs include the cost of payday or car-title loans. Nonetheless, as will be discussed below, the sizable cost difference between checking accounts and GPR prepaid cards stems from overdraft related fees charged to checking account holders.

In contrast, for consumers who do not make overdraft transactions and short-term loans, GPR prepaid cards are more costly than checking accounts. The average total cost of GPR ranges from $\$ 5$ to $\$ 18$, while that of checking is $\$ 2$ or $\$ 3$ (Table 3, Pane B). One of the factors contributing to the higher GPR total cost is fees assessed for ATM transactions.

These two results — checking accounts are more costly than GPR cards for overdrafters and GPR cards are more costly than checking accounts for non-overdrafters-are qualitatively consistent with the results of Pew Charitable Trusts (2012). Our study, however, estimates the 
levels of the costs of checking accounts and GPR cards slightly higher than those estimated in the Pew study.

The total cost of AFS has the widest range among the three types of products. For consumers who use overdraft capability or other short-term credit products, using AFS products are less costly than using checking accounts, but could be less or more costly than using GPR prepaid cards, depending on the AFS provider. For consumers who do not use short-term credit products, using AFS products is more costly than using checking accounts, but again could be more or less costly than using GPR prepaid cards.

Among checking accounts, those offered by the largest national banks tend to be more costly for both overdrafters and non-overdrafters than those offered by large regional and small community banks. Among GPR cards, those offered by nonbanks are generally more costly than those offered by banks. Below we will provide detailed costs of each product type.

\subsection{Detailed costs}

\subsubsection{Costs of checking accounts}

Checking accounts have three major cost components - a monthly fee, ATM related fees, and overdraft related fees. ${ }^{23}$ For overdrafters, all three components influence the total cost of holding and using a checking account, while for non-overdrafters, only the first two components affect the total cost.

Many banks offer conditionally-free checking accounts: if a consumer meets certain criteria, he can waive a monthly fee or pay a reduced monthly fee. The criteria typically include either a minimum balance or a minimum value of monthly deposits, or both. Although both types of consumers in our models are assumed to have a low average daily balance $(\$ 119$ for

\footnotetext{
${ }^{23}$ The total cost also includes other fees, such as a monthly card fee and a debit card per transaction fee. These fees are rarely assessed.
} 
overdrafters and $\$ 125$ for non-overdrafters), their monthly deposits amounts assumed-\$1,439 for overdrafters and \$1,091 for non-overdrafters — often meet the requirement of minimum value of monthly deposits. As a result, both types of consumers often do not incur a monthly fee and the average monthly fee is at most $\$ 1.21$ (Table 4).

Two types of fees may be assessed to checking account holders for their use of ATMs. Many banks assess a so-called "foreign" fee when their account holders use an ATM outside of their ATM network. Account holders may also be assessed a surcharge by the ATM owner if the owner is not their own bank or the owner does not join a surcharge-free network. While each bank's fee schedule provides foreign fee information, it does not provide information about surcharge fees. Thus, we assume a $\$ 2.50$ surcharge, which corresponds with the mean value of an ATM surcharge paid by NetSpend cardholders (Hayashi and Cuddy 2014a). In contrast, when account holders use their bank's ATM, they typically incur no surcharge and no fee assessed by their bank. Thus, we assume no fee incurred by checking account holders for their use of in-network ATMs unless each bank's fee schedule suggests otherwise. As mentioned in the previous section, 85 percent of ATM transactions made by checking account holders are assumed to be at in-network ATMs.

The average cost of using ATMs per month is at most $\$ 3$ for overdrafters and $\$ 2$ for nonoverdrafters (Table 4). The results suggest that the largest national banks tend to charge higher ATM fees than large regional and small community banks.

Care is required to estimate costs related to overdrafts. As CFPB (2013) reported, there is a significant variation across overdraft programs and associated fees offered to checking account holders. Some banks do not assess an overdraft fee if the amount of the overdraft is less than a certain threshold (typically \$5), or if the account holders bring their account balance back to zero 
or positive by the end of business day that they make an overdraft. Some banks assess an extended overdrawn fee, in addition to an overdraft fee, if the negative balance continues for a certain number of days after the overdraft is made.

The overdraft cost is significantly larger than the other two cost components. The average overdraft cost is $\$ 107$ for largest national banks, \$99 for large regional banks, and $\$ 83$ for small community banks. In our model of overdrafters, we assume overdrafters make three separate overdraft transactions per month, each with a negative balance lasting four days. This assumption reduces the cost related to overdraft because some banks assess extended overdrawn fees if account holders keep their account negative for five days or longer. Therefore, our results here should be viewed as the low-end cost estimation of checking accounts. If we instead assume overdrafters make three overdraft transactions in a day and the negative balance continues for 12 consecutive days every month, the average overdraft cost increases to $\$ 130$ for the largest national banks, \$111 for large regional banks, and \$94 for small community banks.

Because of the overdraft cost, the total cost of checking accounts for overdrafters is more than 30 times larger than that for non-overdrafters. The overdraft cost accounts for more than 95 percent of the total cost incurred by overdrafters. Although the largest national banks also assess a higher ATM fee than large regional or small community banks, the cost difference across the three groups of banks is more pronounced by the overdraft cost.

\subsubsection{Costs of GPR prepaid cards}

GPR prepaid cards have six major cost components (Table 5). ${ }^{24}$ The first two are fees related to purchase transactions. As mentioned in the previous section, the two most common fee

\footnotetext{
${ }^{24}$ In addition to these six components, GPR cardholders may be assessed a one-time card acquisition fee (or an initial load fee). The average fee amount is about $\$ 3$ (including those cards that do not assess such a fee). Since the average lifespan of cards held by GPR cardholders who receive direct deposits each month is longer than 2 years
} 
programs are monthly fee programs, which assess a fixed monthly fee but do not assess a pertransaction fee to each purchase transaction, and pay-as-you-go programs, which assess a pertransaction fee but no monthly fee. Most GPR products in our sample assess either a monthly fee or per-transaction fee, with a few exceptions.

For both overdrafters and non-overdrafters, the average monthly fee of GPR prepaid cards offered by nonbanks is slightly higher than $\$ 4$, while that offered by banks is about $\$ 3$. Both overdrafters and non-overdrafters incur no per-transaction fee if they hold GPR prepaid cards offered by banks. But if they hold GPR cards offered by nonbanks, overdrafters incur $\$ 1.23$ (the weighted average of $\$ 0$ for cards with overdraft and $\$ 1.33$ for cards without overdraft) for per-transaction fees in a month on average, and non-overdrafters incur $\$ 0.86$.

Similar to checking accounts, two other cost components of GPR prepaid cards are ATM costs, as well as overdraft or the cost of an AFS loan. ATM costs for cardholders of GPR cards offered by banks are comparable to the ATM costs for checking account holders, but those for cardholders of GPR cards offered by nonbanks are more than 5 times greater (around $\$ 16$ for overdrafters and \$11 for non-overdrafters). The difference in ATM costs between banks' vs. nonbanks' GPR cards is mainly due to the distribution of in- vs. out-of-network ATM transactions. As mentioned in the previous section, we assume the share of in-network ATM transactions for banks' GPR cards is the same as those for checking accounts ( 85 percent), which is substantially greater than the share of in-network (or surcharge-free) ATM transactions for nonbanks' GPR cards (7 percent). A rationale for this assumption is a bank's in-network ATMs

(2.9 years for overdrafters and 2.3 years for non-overdrafters), the total cost incurred by GPR cardholders in a month is rarely affected by the card acquisition fee if we spread out the fee over these timespans. Another fee assessed to GPR cardholders is a card replacement fee, which is also assessed to checking account holders. The frequency with which GPR cardholders have replaced their card is unobservable in our data, but it may be reasonable to believe that these occurrences are rare. Even if we were to assume that GPR cardholders replace their card once every year, the total cost incurred by GPR cardholders in a month would increase by less than $\$ 1$. Thus, these fees would not significantly affect the total cost of GPR cards. 
may be more easily accessible for not just the bank's checking account holders but also its GPR cardholders than a nonbank GPR provider's in-network (or surcharge-free) ATMs. However, the difference of in-network ATM use between actual checking account holders and GPR cardholders could also be explained by behavioral factors. For example, GPR cardholders may tend to use the closest ATM, while checking account holders may look for and use the least expensive ATM. As behavioral factors play more roles in selecting which ATMs to use, the ATM costs of banks' and nonbanks' GPR cards would converge.

The average overdraft cost for GPR cards with overdraft capability (i.e., NetSpend cards) is $\$ 12.00$, while the average cost of short-term credit for GPR cards without overdraft capability is $\$ 19.50$ or $\$ 32.50$. The overdraft cost of NetSpend cards is also significantly smaller than that of checking accounts for two reasons. First, the fee per overdraft for NetSpend cards is $\$ 15$, which is significantly lower than that for checking accounts. As Table 4 suggests, the average fee per overdraft for checking accounts is $\$ 36(=\$ 107 / 3)$ for the largest national banks, $\$ 33$ (=\$99/3) for large regional banks, and \$28 (=\$83/3) for small community banks. Second, NetSpend cardholders can avoid incurring overdraft fees via the 24-hour grace period and declined transactions that exceed the maximum overdrawn amount set by NetSpend.

The rest of the cost components — balance inquiry cost and cash load cost — are unique to GPR prepaid cards. While almost all banks offer free-of-charge balance inquiry services for checking account as well as GPR card customers, some nonbank providers of GPR cards charge a balance inquiry fee. As a result, the average balance inquiry cost per month for cardholders with nonbanks' GPR cards is $\$ 1.36$ for overdrafters and $\$ 1.69$ for non-overdrafters.

The cost of cash loads are estimated in a range of values. Cardholders can reload funds to their GPR prepaid cards with cash at various retailers that participate in the GPR provider's 
reload network. Some retailers offer the cash load service for free, while others charge a fee. The maximum cash load fee varies by GPR provider, but it is typically either $\$ 3.95$ or $\$ 4.95$ per load. The average cash load cost is smaller for banks' GPR cards. Because of their fewer cash loading occurrences, overdrafters incur smaller cash load cost than non-overdrafters.

Compared with the overdraft cost of a checking account, the overdraft or AFS credit cost of GPR cards is modest. For overdrafters, the overdraft or AFS credit cost accounts for 40 to 50 percent of the total cost of nonbanks' GPR cards or over 70 percent of the total cost of banks' GPR cards. Due to the modest cost of overdraft or AFS credit, the total cost of GPR cards for overdrafters is only 2 to 4 times greater than that for non-overdrafters.

\subsubsection{Costs of AFS products}

In our models, we assume consumers who solely depend on AFS products use three services: AFS credit, check-cashing, and money orders or remittances for bill payments. As explained above, the cost of AFS credit is either $\$ 19.50$ or $\$ 32.50$ (Table 6).

The cost of check-cashing services has a wide range. If consumers in our model use the service offered by large retailers, the check-cashing cost is $\$ 7.80$ for overdrafters and $\$ 7.50$ for non-overdrafters. However, if they use the service offered by check-cashing providers, their cost is significantly higher: $\$ 43.17$ for overdrafters and $\$ 32.73$ for non-overdrafters.

To pay bills, we assume consumers use money orders or bill payment services. Large retailers typically offer the service for a lower fee than banks $(\$ 1.40$ vs. $\$ 10.00$ for overdrafters and $\$ 0.98$ vs. $\$ 7.00$ for non-overdrafters). The cost of using money orders at the USPS is inbetween ( $\$ 2.50$ for overdrafters and $\$ 1.75$ for non-overdrafters).

The combination of these three costs results in a wide range of total costs. For overdrafters, the total cost ranges between $\$ 29$ and $\$ 86$, while it ranges from $\$ 8$ to $\$ 40$ for non- 
overdrafters. Although both overdrafters and non-overdrafters could incur a lower cost by solely depending on AFS products than by using GPR cards, one clear disadvantage in AFS products is that no AFS product allows consumers to make online transactions. Recently, more purchases have shifted from brick-and-mortar merchants to online merchants. In fact, about 40 percent of purchases GPR cardholders make are at online merchants. The opportunity cost of inability to access online merchants could be large. The easiest way for unbanked consumers to access online merchants may be holding a general-purpose prepaid card.

\subsection{Costs for consumers who occasionally overdraw their accounts}

The cost rankings of checking accounts versus GPR cards are clear for consumers who regularly overdraw their accounts and for consumers who never overdraw their accounts. Which products are less costly for consumers who occasionally overdraw their accounts? This question can be answered with our data.

As discussed above, a consumer incurs $\$ 36$ per overdraft, on average, if he has a checking account at one of the largest national banks. If instead he has a GPR card offered by NetSpend, he incurs a $\$ 15$ fee per overdraft. The difference in the cost per overdraft is $\$ 21$. For non-overdrafters, the annualized fee for NetSpend's GPR cards is $\$ 189.48$ greater than the average annualized fee for checking accounts offered by the largest banks $(\$ 189.48=\$ 19.15 \times 12$ $\$ 3.36 \times 12$ ). Thus, if a consumer makes more than nine overdraft transactions in a year (i.e., three overdrafts in every four months), this consumer can save his annualized total cost by having a GPR card offered by NetSpend.

In our model, a consumer holding a GPR card without overdraft capability would use a payday or car-title loan as a substitute for overdraft. Using payday loans could be less costly than using NetSpend's overdraft capability. While some payday lenders set the minimum loan amount 
at $\$ 100$, others set it at $\$ 50$. If a consumer's payday loan amount needed to substitute an overdraft transaction is $\$ 100$ or less, and if the consumer repays the loan in two weeks, using payday loans is as costly as, or less costly (if the loan amount less than $\$ 100$ is available) than, using NetSpend's overdraft capability. However, if the consumer takes four weeks to repay the loan, even if the loan amount is $\$ 50$, the cost exceeds $\$ 15 .{ }^{25}$ Using car-title loans, however, may be more costly than using NetSpend's overdraft capability. Since the minimum loan amount is typically set at $\$ 100$, a consumer needs to borrow at least $\$ 100$ to substitute an occasional overdraft even if the amount of overdraft is less than $\$ 100 .{ }^{26}$ The financial charge for a $\$ 100$ cartitle loan is $\$ 25$, which is more expensive than NetSpend's overdraft fee of $\$ 15$.

To conclude the section, we should note non-sufficient funds (NSF) fees, which are assessed for checks, $\mathrm{ACH}$, and recurring debit card transactions if a checking account holder's balance is not sufficient to cover those transactions. ${ }^{27}$ Our consumer models implicitly assume checking account holders make either ATM or debit card transactions, but in reality, some checking account holders also use checks and $\mathrm{ACH}$ for their payments. Although a checking account holder can avoid overdraft fees assessed for ATM or one-time debit transactions by not opting in to overdraft programs, he may still incur NSF fees. Thus, the cost of checking accounts for non-overdrafters could be higher than our estimates if they do not pay attention to their choice of payment methods and account balance to avoid NSF fees. Since a NSF fee is generally the same amount as an overdraft fee and GPR prepaid providers do not assess NSF fees, the

\footnotetext{
${ }^{25}$ The total cost is $\$ 16.13$. In the first two weeks he incurs $\$ 7.5(=\$ 50 * 0.15)$ and in the second two weeks he incurs an additional $\$ 8.63\left(=\$ 57.5^{*} 0.15\right)$.

${ }^{26}$ On average, car title loans are for $\$ 100$ to $\$ 5,500$, according to the Federal Trade Commission (http://www.consumer.ftc.gov/articles/0514-car-title-loans).

${ }^{27}$ A recurring debit card transaction is a transaction in which the cardholder provides his debit card details to a company such as a biller and authorizes a series of payments to be taken from his bank account associated with the debit card.
} 
annual cost of checking accounts exceeds that of GPR cards if non-overdrafters incur six or more NSF fees in a year. ${ }^{28}$

\section{Conclusion}

Our models and fee data have shown that the cost of GPR prepaid cards to unbanked consumers is highly dependent on overdraft behavior. For consumers who regularly make overdraft transactions, GPR prepaid cards are substantially less costly than checking accounts. In contrast, for consumers who do not need overdraft capability and short-term credit, checking accounts are less costly than GPR prepaid cards. Consumers who occasionally make overdraft transactions - consumers who are in-between the two consumer models - may be able to reduce their total costs by holding a GPR prepaid card instead of holding a checking account, if they make nine overdraft transactions in a year.

The cost difference across the three types of products explains why unbanked consumers who regularly or occasionally make overdrafts or use short-term credit choose GPR prepaid cards over checking accounts. However, it does not explain why unbanked non-overdrafters use GPR prepaid cards instead of holding and using checking accounts more exclusively. Further research is required to understand determinants of the unbanked non-overdrafters' choice of financial products.

Although AFS credit products are perceived as very costly, our study has found some products, especially payday loans, could be less costly than overdraft programs offered for checking accounts or GPR prepaid cards, as long as the amount of loans is adequately small (less than $\$ 100$ per overdraft incident) and the loan is quickly repaid. Nevertheless, policymakers may not want to encourage underserved consumers to use AFS credit products as an alternative to

\footnotetext{
${ }^{28}$ GPR prepaid providers assess a decline fee of $\$ 1$ or less. Thus, the number of NSF fees that balances the annual cost of checking account and that of GPR cards is $5.4=\$ 189.48 /(\$ 36-\$ 1)$.
} 
opting in to an overdraft program because if those consumers start borrowing a larger amount, they might be at risk of being drawn into a cycle of debt. Instead, policymakers could consider policy that induces banks and providers of GPR prepaid cards to reduce fee burdens associated with overdrafts or to make short-term credit more accessible and affordable for underserved consumers. 


\section{Table 1: Monthly activities of overdrafters and non-overdrafters}

\begin{tabular}{|c|c|c|}
\hline & Overdrafters & Non-overdrafters \\
\hline \multicolumn{3}{|l|}{ Loads } \\
\hline Loads (\#) & 2.57 & 2.45 \\
\hline Direct deposits (\#) & 2.13 & 1.76 \\
\hline Cash loads $(\#)$ & 0.45 & 0.69 \\
\hline Loads $(\$)$ & $\$ 1,438.92$ & $\$ 1090.93$ \\
\hline Direct deposits $(\$)$ & $\$ 1,335.31$ & $\$ 965.35$ \\
\hline Cash loads $(\$)$ & $\$ 103.60$ & $\$ 125.57$ \\
\hline \multicolumn{3}{|l|}{ ATM transactions } \\
\hline ATM transactions (\#) & 3.35 & 2.48 \\
\hline ATM transactions $(\$)$ & $\$ 410.73$ & $\$ 320.68$ \\
\hline \multicolumn{3}{|l|}{ Purchase transactions } \\
\hline Purchase transactions (\#) & 20.15 & 13.91 \\
\hline PIN $(\#)$ & 7.48 & 5.33 \\
\hline Signature, card-present (\#) & 4.81 & 3.61 \\
\hline Signature, card-not-present (\#) & 7.86 & 4.97 \\
\hline Of which paid to billers (\#) & 2.00 & 1.40 \\
\hline Purchase transactions $(\$)$ & $\$ 807.98$ & $\$ 569.16$ \\
\hline PIN (\$) & $\$ 330.93$ & $\$ 251.85$ \\
\hline Signature, card-present (\$) & $\$ 122.72$ & $\$ 100.42$ \\
\hline Signature, card-not-present (\$) & $\$ 354.33$ & $\$ 216.89$ \\
\hline Of which paid to billers $(\$)$ & $\$ 189.55$ & $\$ 130.84$ \\
\hline \multicolumn{3}{|l|}{ Bill payments via $\mathrm{ACH}$} \\
\hline Bill payments via $\mathrm{ACH}(\#)$ & 0.02 & 0.01 \\
\hline Bill payments via $\mathrm{ACH}(\$)$ & $\$ 5.33$ & $\$ 2.30$ \\
\hline \multicolumn{3}{|l|}{ Overdraft } \\
\hline Overdraft buffers (\#) & 0.71 & 0.87 \\
\hline Overdrafts $(\#)$ & 2.52 & 0 \\
\hline Incurred overdraft fees (\#) & 0.84 & 0 \\
\hline \multicolumn{3}{|l|}{ Declined transactions } \\
\hline Declined ATM transactions (\#) & 0.64 & 0.25 \\
\hline Declined purchase transactions (\#) & 0.07 & 0.03 \\
\hline Declined ACH transactions (\#) & 0.05 & 0.02 \\
\hline \multicolumn{3}{|l|}{ Balance inquiries } \\
\hline via $\operatorname{ATM}(\#)$ & 0.42 & 0.54 \\
\hline via customer service call (\#) & 1.33 & 1.51 \\
\hline \multicolumn{3}{|l|}{ Other } \\
\hline Average daily balance $(\$)$ & $\$ 119.09$ & $\$ 125.00$ \\
\hline Days with negative balance in a month & 12.3 days & 8.5 days \\
\hline
\end{tabular}


Table 2A: Consumer model: Overdrafters

\begin{tabular}{|c|c|c|c|}
\hline & Checking accounts & GPR prepaid cards & AFS \\
\hline Loads & $\begin{array}{l}\text { - } 2.6 \text { deposits with the total } \\
\text { amount of } \$ 1,439 \text { per } \\
\text { month } \\
\text { - Among them, } 2.1 \text { deposits } \\
\text { are direct deposits with } \\
\$ 1,335 \\
\text { - The rest are other types of } \\
\text { deposits }\end{array}$ & $\begin{array}{l}\text { - } 2.6 \text { loads with the total amount } \\
\text { of } \$ 1,439 \text { per month } \\
\text { - Among them, } 2.1 \text { loads are } \\
\text { direct deposits with } \$ 1,335 \\
\text { - } 0.5 \text { cash loads with the total } \\
\text { amount of } \$ 104\end{array}$ & $\begin{array}{l}\text { - } 2.6 \text { check-cashing per } \\
\text { month } \\
\text { - Each check amount is } \\
\$ 553\end{array}$ \\
\hline Purchases & \multicolumn{2}{|c|}{$\begin{array}{l}\text { - } 20.2 \text { purchases per month } \\
\text { - With } 7.5 \text { PIN, } 4.8 \text { signature CP, and } 7.9 \text { signature CNP } \\
\text { - Among them, } 2.0 \text { transactions with the total amount of } \$ 190 \\
\text { ( } \$ 95 \text { each) are paid to billers }\end{array}$} & $\begin{array}{l}\text { - Two } \$ 95 \text { bill payments } \\
\text { using money orders or } \\
\text { remittance per month }\end{array}$ \\
\hline ATM & $\begin{array}{l}\text { - 4.0 ATM cash withdrawals } \\
\text { per month } \\
\text { - Among them, } 3.4 \text { are in- } \\
\text { network and } 0.6 \text { are out-of- } \\
\text { network }\end{array}$ & $\begin{array}{l}\text { - } 3.4 \text { successful and } 0.6 \text { declined } \\
\text { ATM withdrawals per month } \\
\text { - For nonbanks' GPR } \\
\text { cardholders, } 0.2 \text { are in-network } \\
\text { and } 3.2 \text { are out-of-network } \\
\text { - For banks' GPR cardholders, } \\
2.9 \text { are in-network and } 0.5 \text { are } \\
\text { out-of-network }\end{array}$ & - Inapplicable \\
\hline Overdraft & $\begin{array}{l}\text { - } 3.0 \text { overdrafts with the total } \\
\text { value of } \$ 156 \text { per month }\end{array}$ & $\begin{array}{l}\text { For cardholders of GPR with } \\
\text { overdraft capability } 2.5 \\
\text { overdrafts with the total value } \\
\text { of } \$ 130 \text { and } 0.8 \text { of which incur } \\
\text { overdraft fees per month } \\
\text { - For cardholders of GPR } \\
\text { without overdraft capability, } \\
\text { no overdraft but AFS credits } \\
\text { of } \$ 130 \text { per month }\end{array}$ & $\begin{array}{l}\text { - AFS loans of } \$ 130 \text { per } \\
\text { month }\end{array}$ \\
\hline $\begin{array}{l}\text { Balance } \\
\text { inquiries }\end{array}$ & $\begin{array}{l}\text { - } 1.7 \text { balance inquiries } \\
\text { - Among them, } 0.4 \text { are via } \\
\text { ATM without incurring } \\
\text { surcharges and } 1.3 \text { are via } \\
\text { customer service calls }\end{array}$ & $\begin{array}{l}\text { - } 1.7 \text { balance inquiries } \\
\text { - For nonbanks' GPR } \\
\text { cardholders, } 0.4 \text { are via ATM } \\
\text { with incurring surcharges and } \\
1.3 \text { are via customer service } \\
\text { calls } \\
\text { - For banks' GPR cardholders, } \\
0.4 \text { are via ATM without } \\
\text { incurring surcharges and } 1.3 \text { are } \\
\text { via customer service calls }\end{array}$ & - Inapplicable \\
\hline Balance & \multicolumn{2}{|c|}{$\begin{array}{l}\text { - Average daily balance of } \$ 119 \\
\text { - } 12 \text { days with negative balance in a month }\end{array}$} & - Inapplicable \\
\hline
\end{tabular}




\section{Table 2B: Consumer model: Non-overdrafters}

\begin{tabular}{|c|c|c|c|}
\hline & Checking account & GPR prepaid card & AFS \\
\hline Loads & $\begin{array}{l}\text { - } 2.5 \text { deposits with the total } \\
\text { amount of } \$ 1,091 \text { per } \\
\text { month } \\
\text { - Among them, } 1.8 \text { deposits } \\
\text { are direct deposits with } \$ 965 \\
\text { - The rest are other types of } \\
\text { deposits }\end{array}$ & $\begin{array}{l}\text { - } 2.5 \text { loads with the total } \\
\text { amount of } \$ 1,091 \text { per } \\
\text { month } \\
\text { - Among them, } 1.8 \text { loads are } \\
\text { direct deposits with } \$ 965 \\
\text { - } 0.7 \text { cash loads with the total } \\
\text { amount of } \$ 126\end{array}$ & $\begin{array}{l}\text { - } 2.5 \text { check-cashing per } \\
\text { month } \\
\text { - Each check amount is } \$ 436\end{array}$ \\
\hline Purchases & \multicolumn{2}{|c|}{$\begin{array}{l}\text { - } 13.9 \text { purchases per month } \\
\text { - With 5.3 PIN, } 3.6 \text { signature CP, and 5.0 signature CNP } \\
\text { - Among them, } 1.4 \text { transactions with the total amount of } \$ 131 \\
\text { ( } \$ 94 \text { each) are paid to billers }\end{array}$} & $\begin{array}{l}\text { - Two } \$ 94 \text { bill payments using } \\
\text { money orders or remittance } \\
\text { per month }\end{array}$ \\
\hline ATM & $\begin{array}{l}\text { - } 2.5 \text { successful and } 0.3 \\
\text { declined ATM cash } \\
\text { withdrawals per month } \\
\text { - Among them, } 2.1 \text { are in- } \\
\text { network and } 0.4 \text { are out-of- } \\
\text { network }\end{array}$ & $\begin{array}{l}\text { - } 2.5 \text { successful and } 0.3 \\
\text { declined ATM withdrawals } \\
\text { per month } \\
\text { - } \text { For nonbanks' GPR } \\
\text { cardholders, } 0.2 \text { are in- } \\
\text { network and } 2.3 \text { are out-of- } \\
\text { network } \\
\text { - For banks' GPR } \\
\text { cardholders, } 2.1 \text { are in- } \\
\text { network and } 0.4 \text { are out-of- } \\
\text { network }\end{array}$ & - Inapplicable \\
\hline Overdraft & \multicolumn{3}{|l|}{ - Inapplicable } \\
\hline $\begin{array}{l}\text { Balance } \\
\text { inquiries }\end{array}$ & $\begin{array}{l}\text { - } 2.0 \text { balance inquiries } \\
\text { - Among them, } 0.5 \text { are via } \\
\text { ATM without incurring } \\
\text { surcharges and } 1.5 \text { are via } \\
\text { customer service calls }\end{array}$ & $\begin{array}{l}\text { - } 2.0 \text { balance inquiries } \\
\text { - For nonbanks' GPR } \\
\text { cardholders, } 0.5 \text { are via } \\
\text { ATM with incurring } \\
\text { surcharges and } 1.5 \text { are via } \\
\text { customer service calls } \\
\text { - For banks' GPR } \\
\text { cardholders, } 0.5 \text { are via } \\
\text { ATM without incurring } \\
\text { surcharges and } 1.5 \text { are via } \\
\text { customer service calls }\end{array}$ & - Inapplicable \\
\hline Balance & \multicolumn{2}{|c|}{ - Average daily balance of $\$ 125$} & - Inapplicable \\
\hline
\end{tabular}




\section{Table 3: Total cost per month by product type}

\section{A: Overdrafters}

\begin{tabular}{|c|c|c|c|c|c|c|c|}
\hline & \multicolumn{3}{|c|}{ Checking account } & \multicolumn{3}{|c|}{ GPR card ${ }^{b}$} & \multirow[t]{3}{*}{ AFS } \\
\hline & \multirow{2}{*}{$\begin{array}{l}\text { Largest } \\
\text { national }\end{array}$} & \multirow{2}{*}{$\begin{array}{l}\text { Large } \\
\text { regional }\end{array}$} & \multirow{2}{*}{$\begin{array}{c}\text { Small } \\
\text { community }\end{array}$} & \multicolumn{2}{|c|}{ Nonbank } & Bank $^{\mathrm{c}}$ & \\
\hline & & & & $\begin{array}{c}\text { With } \\
\text { overdraft }\end{array}$ & $\begin{array}{c}\text { Without } \\
\text { overdraft }\end{array}$ & $\begin{array}{l}\text { Without } \\
\text { overdraft }\end{array}$ & \\
\hline Mean & $\$ 111.72$ & $\$ 101.64$ & $\$ 86.22$ & $\$ 37.53$ & $\$ 57.46$ & $\$ 39.64$ & \\
\hline Median & $\$ 111.00$ & $\$ 99.75$ & $\$ 83.40$ & & $\$ 56.26$ & $\$ 39.85$ & \\
\hline $25^{\text {th }}$ percentile & $\$ 108.00$ & $\$ 86.18$ & $\$ 77.10$ & & $\$ 53.24$ & $\$ 38.96$ & \\
\hline $75^{\text {th }}$ percentile & $\$ 115.20$ & $\$ 113.95$ & $\$ 92.70$ & & $\$ 61.06$ & $\$ 41.04$ & \\
\hline Min & & & & & & & $\$ 28.70$ \\
\hline Max & & & & & & & $\$ 85.67$ \\
\hline $\begin{array}{l}\text { Number of } \\
\text { observations }\end{array}$ & 27 & 42 & 47 & 1 & 13 & 10 & n.a. \\
\hline
\end{tabular}

\section{B: Non-overdrafters}

\begin{tabular}{|l|c|c|c|c|c|c|}
\hline & \multicolumn{3}{|c|}{ Checking account } & \multicolumn{2}{c|}{ GPR carde } & \multirow{2}{*}{ AFS } \\
\hline & $\begin{array}{c}\text { Largest } \\
\text { national }\end{array}$ & $\begin{array}{c}\text { Large } \\
\text { regional }\end{array}$ & $\begin{array}{c}\text { Small } \\
\text { community }\end{array}$ & Nonbank & Bank & \\
\hline Mean & $\$ 3.41$ & $\$ 1.86$ & $\$ 2.36$ & $\$ 18.21$ & $\$ 4.96$ & \\
\hline Median & $\$ 2.00$ & $\$ 1.60$ & $\$ 1.60$ & $\$ 18.52$ & $\$ 5.88$ & \\
\hline $25^{\text {th }}$ percentile & $\$ 1.80$ & $\$ 1.00$ & $\$ 1.00$ & $\$ 14.42$ & $\$ 2.75$ & \\
\hline $75^{\text {th }}$ percentile & $\$ 3.60$ & $\$ 1.80$ & $\$ 2.36$ & $\$ 20.96$ & $\$ 6.69$ & \\
\hline Min & & & & & & $\$ 8.48$ \\
\hline Max & & & & 14 & 10 & n.a. \\
\hline $\begin{array}{l}\text { Number of } \\
\text { observations }\end{array}$ & 29 & 43 & 48 & & & \\
\hline
\end{tabular}

Notes:

a: Overdrafters are assumed to make at most one overdraft transaction in a day and each overdraft transaction results in four consecutive days of negative balance in their account.

b: For each product, the total cost varies depending on where GPR cardholders make cash loads. Here uses the highest cost estimates.

c: In this table, bank issued GPR cardholders are assumed to access in-network ATMs more easily than nonbank issued GPR cardholders.

d: Among GPR providers in our sample, only NetSpend offers an overdraft program.

e: For each product, the total cost varies depending on where GPR cardholders make cash loads. Here uses the lowest cost estimates. 


\section{Table 4: Average cost of checking accounts per month}

\section{A: Overdrafters}

\begin{tabular}{|l|c|c|c|}
\hline & Largest national bank & Large regional bank & Small community bank \\
\hline Monthly fee & $\$ 1.21$ & $\$ 0.70$ & $\$ 0.98$ \\
\hline ATM cost & $\$ 2.79$ & $\$ 1.85$ & $\$ 1.90$ \\
\hline Overdraft cost & $\$ 107.01$ & $\$ 99.06$ & $\$ 83.18$ \\
\hline Total cost & $\$ 111.72$ & $\$ 101.64$ & $\$ 86.22$ \\
\hline
\end{tabular}

\section{B: Non-overdrafters}

\begin{tabular}{|l|c|c|c|}
\hline & Largest national bank & Large regional bank & Small community bank \\
\hline Monthly fee & $\$ 1.21$ & $\$ 0.61$ & $\$ 0.98$ \\
\hline ATM cost & $\$ 1.86$ & $\$ 1.23$ & $\$ 1.27$ \\
\hline Total cost & $\$ 3.41$ & $\$ 1.86$ & $\$ 2.36$ \\
\hline
\end{tabular}

Table 5: Average cost of GPR prepaid cards per month

\section{A: Overdrafters}

\begin{tabular}{|l|c|c|c|}
\hline \multirow{2}{*}{} & \multicolumn{2}{|c|}{ Nonbank } & Bank \\
\cline { 2 - 4 } & With overdraft & Without overdraft & Without overdraft \\
\hline Monthly fee & $\$ 5.00$ & $\$ 4.28$ & $\$ 2.99$ \\
\hline Per transaction fee cost & $\$ 0.00$ & $\$ 1.33$ & $\$ 0.00$ \\
\hline ATM cost & $\$ 16.70$ & $\$ 15.66$ & $\$ 2.52$ \\
\hline Overdraft/AFS credit cost & $\$ 12.00$ & $\$ 19.50-\$ 32.50$ & $\$ 19.50-\$ 32.50$ \\
\hline Balance inquiry cost & $\$ 1.85$ & $\$ 1.33$ & $\$ 0.00$ \\
\hline Cash load cost & $\$ 0.00-\$ 1.98$ & $\$ 0.00-\$ 2.36$ & $\$ 0.00-\$ 1.64$ \\
\hline Total cost & $\$ 35.55-\$ 37.53$ & $\$ 42.10-\$ 57.46$ & $\$ 25.01-\$ 39.64$ \\
\hline
\end{tabular}

B: Non-overdrafters

\begin{tabular}{|l|c|c|}
\hline & Nonbank & Bank \\
\hline Monthly fee & $\$ 4.34$ & $\$ 2.99$ \\
\hline Per transaction fee cost & $\$ 0.86$ & $\$ 0.00$ \\
\hline ATM cost & $\$ 11.33$ & $\$ 1.97$ \\
\hline Balance inquiry cost & $\$ 1.69$ & $\$ 0.00$ \\
\hline Cash load cost & $\$ 0.00-\$ 3.27$ & $\$ 0.00-\$ 2.29$ \\
\hline Total cost & $\$ 18.21-\$ 21.48$ & $\$ 4.96-\$ 7.25$ \\
\hline
\end{tabular}

Table 6: Cost of AFS per month

\begin{tabular}{|l|c|c|}
\hline & Overdrafters & Non-overdrafters \\
\hline AFS credit cost & $\$ 19.50-\$ 32.50$ & n.a. \\
\hline Check-cashing cost & $\$ 7.80-\$ 43.17$ & $\$ 7.50-\$ 32.73$ \\
\hline Bill payment cost & $\$ 1.40-\$ 10.00$ & $\$ 0.98-\$ 7.00$ \\
\hline Total cost & $\$ 28.70-\$ 85.67$ & $\$ 8.48-\$ 39.73$ \\
\hline
\end{tabular}




\section{References}

Barr, Michael S. 2012. No Slack: The Financial Lives of Low-Income Americans. Washington, DC: Brookings Institution Press.

Bell, Claes. 2011. "Check Cashing: Still Not a Good Deal,” Bankrate.com, November 18, available at: http://www.bankrate.com/financing/banking/check-cashing-still-not-a-gooddeal/.

Bretton Woods, Inc. 2013. Analysis of General Purpose Reloadable Prepaid Cards: A comparative Cost Analysis of GPR Cards using Program Manager and Issuer Data, November.

Consumer Financial Protection Bureau. 2013. CFPB Study of Overdraft Programs: A White Paper of Initial Data Findings, June.

Consumer Reports. 2013. Prepaid Cards: How They Rate on Value, Convenience, Safety and Fee Accessibility and Clarity, July.

Edmiston, Kelly. 2011. “Could Restrictions on Payday Lending Hurt Consumers?” Federal Reserve Bank of Kansas City Economic Review, First Quarter.

Federal Deposit Insurance Corporation. 2008. FDIC Study of Bank Overdraft Programs, November.

Federal Deposit Insurance Corporation. 2014. 2013 FDIC National Survey of the Unbanked and Underbanked Households, October.

Federal Reserve Bank of Kansas City. 2010. "A Study of the Unbanked and Underbanked Consumer in the Tenth Federal Reserve District," May.

Federal Reserve System. 2014. The 2013 Federal Reserve Payments Study: Detailed Report and Updated Data Release.

Government Accountability Office. 2013. Automated Teller Machines: Some Consumer Fees Have Increased, April.

Hayashi, Fumiko and Emily Cuddy. 2014a. "General Purpose Reloadable Prepaid Cards:

Penetration, Use, Fees and Fraud Risks," Federal Reserve Bank of Kansas City Research Working Papers, WP14-01.

Hayashi, Fumiko and Emily Cuddy. 2014b. "Recurrent Overdrafts: A Deliberation Decision by Some Prepaid Cardholders?” Federal Reserve Bank of Kansas City Research Working Papers, WP14-08. 
Herbst-Murphy, Susan and Greg Weed. 2014. "Millennials with Money: A New Look at Who Uses GPR Prepaid Cards," Federal Reserve Bank of Philadelphia Payment Card Center Discussion Paper, September.

Jun, Michelle. 2010. Prepaid Cards: Second-Tier Bank Account Substitutes, Consumers Union, September.

Montezemolo, Susanna. 2013. "Car-Title Lending: The State of Lending in America \& its Impact on US Households," Center for Responsible Lending.

Morales, Gerald. 2015. "Money Order Fees Compared at USPS, Western Union, and More," My Bank Tracker, March 20, available at: http://www.mybanktracker.com/news/2013/11/11/comparing-post-office-bank-westernunion-money-order-fees/.

Pew Charitable Trusts. 2012. Loaded With Uncertainty: Are Prepaid Cards a Smart Alternative to Checking Accounts?

Wilshusen, Stephanie, Robert Hunt, James van Ostal, and Rachel Schnider. 2012. "Consumers' Use of Prepaid Cards: A Transaction-Based Analysis," Federal Reserve Bank of Philadelphia Payment Card Center Discussion Paper, August. 